\title{
Hydrochemical Assessment of the Irrigation Water Quality of the El-Salam Canal, Egypt
}

\author{
Yasser A. El-Amier ${ }^{1, *(1)}$, Wafaa K. Kotb ${ }^{1}$, Giuliano Bonanomi ${ }^{2,3}$, Hala Fakhry ${ }^{4}$, Najat A. Marraiki ${ }^{5}$ \\ and Ahmed M. Abd-ElGawad 1,6,*(D)
}

1 Department of Botany, Faculty of Science, Mansoura University, Mansoura 35516, Egypt; w.moataz@gmail.com

2 Department of Agricultural Sciences, University of Naples Federico II, Via Università 100, 80055 Portici, Italy; giuliano.bonanomi@unina.it

3 Task Force on Microbiome Studies, University of Naples Federico II, 80131 Naples, Italy

4 City of Scientific Research and Technological Applications (SRTA-City), New Borg El-Arab City 21934, Egypt; halaelhossany@gmail.com

5 Department of Botany \& Microbiology, College of Science, King Saud University, P.O. Box 2460, Riyadh 11451, Saudi Arabia; najat@ksu.edu.sa

6 Plant Production Department, College of Food \& Agriculture Sciences, King Saud University, P.O. Box 2460, Riyadh 11451, Saudi Arabia

* Correspondence: yasran@mans.edu.eg (Y.A.E.-A.); aibrahim2@ksu.edu.sa (A.M.A.-E.); Tel.: +20-10-1722-9120 (Y.A.E.-A.); +96-65-6268-0864 (A.M.A.-E.)

check for

updates

Citation: El-Amier, Y.A.; Kotb, W.K.; Bonanomi, G.; Fakhry, H.; Marraiki,

N.A.; Abd-ElGawad, A.M.

Hydrochemical Assessment of the Irrigation Water Quality of the El-Salam Canal, Egypt. Water 2021, 13, 2428. https://doi.org/10.3390/ w13172428

Academic Editors: Thomas Meixner, Sheng-Wei Wang and Chihhao Fan

Received: 5 August 2021

Accepted: 31 August 2021

Published: 3 September 2021

Publisher's Note: MDPI stays neutral with regard to jurisdictional claims in published maps and institutional affiliations.

Copyright: (c) 2021 by the authors. Licensee MDPI, Basel, Switzerland. This article is an open access article distributed under the terms and conditions of the Creative Commons Attribution (CC BY) license (https:/ / creativecommons.org/licenses/by/ $4.0 /)$.
Abstract: The El-Salam canal in Egypt is considered an important stream of fresh water for the agricultural sector that extends from the Nile River to Sinai, while it is subjected to several anthropogenic stresses. In this study, five-georeferenced stations (named from S1 to S5) were monitored along the El-Salam Canal before El-Sahara of the Suez Canal, via the estimation of the WQ index based on major cations and anions analysis including salinity hazard, permeability index, residual sodium carbonate, magnesium hazard, sodium percentage, sodium adsorption ratio, Kelley index, potential salinity, total hardness, and irrigation water quality index (IWQI). The sequence of average concentration of cations in water were $\mathrm{Na}^{+}>\mathrm{Ca}^{2+}>\mathrm{Mg}^{2+}>\mathrm{K}^{+}$. The major cations constitute around $60 \%$ of the total dissolved salts. While the sequence of major anions in water were $\mathrm{SO}_{4}{ }^{2-}>\mathrm{HCO}_{3}{ }^{-}>$ $\mathrm{Cl}^{-}>\mathrm{CO}_{3}{ }^{2-}$. These cations and anions showed an increasing trend from $\mathrm{S} 1$ (intake of the canal) to S5 (before El-Sahara) of the El-Salam Canal. Moreover, the order of heavy metals was $\mathrm{Zn}<\mathrm{Cd}<\mathrm{Cr}<$ $\mathrm{Ni}<\mathrm{Fe}<\mathrm{Mn}<\mathrm{Co}<\mathrm{Cu}<\mathrm{Pb}$. According to the US EPA (1999) guidelines, the levels of Fe and $\mathrm{Zn}$ in the El-Salam Canal are within the permissible limits for drinking and irrigation purposes, while Mn, $\mathrm{Pb}, \mathrm{Cu}, \mathrm{Co}, \mathrm{Ni}, \mathrm{Cr}$, and $\mathrm{Cd}$ were detected at higher concentrations than those recommended. The value of IWQI in water samples varied from 40.26 to 114.82. The samples of S1 showed good water, the samples of region S2 (after mixing with Faraskour drainage) showed poor water quality, samples of regions S3 (after mixing with the El-Serw drain waters) and S5 (before El-Sahara) fell under the very poor water category and samples of region S4 (after mixing with the Hadous drainage) showed unsuitable water. Croplands irrigated with such water will not be exposed to any alkaline risks but will be exposed to the risk of salinity, which is more severe after mixing at the S3 and S4 sites. It is recommended to treat the drainage water before mixing with the irrigation water of El-Salam Canal to raise the suitability of irrigation water for crops, particularly for the Hadous drain.

Keywords: irrigation canal; wastewater; agriculture land; heavy metals; water quality indices

\section{Introduction}

Water quality is one of the most essential aspects, since it directly affects human health and other life forms [1]. Water quality monitoring is a crucial tool for achieving long-term development and provides vital information for water management. In many countries with arid or sub-arid climates that are vulnerable to climatic change, surface water quality is 
a delicate and essential problem [2]. Surface water quality in a region is mostly determined by the quality and extent of industrial, agricultural, and other anthropogenic activities in the basins of the specific area [3].

From a technological, economic, social, and political standpoint, managing water resources in the twenty-first century has become an increasingly difficult task [4]. This is especially true in Egypt, where a limited water supply is contending with various and expanding needs. The Egyptian water resources system is made up of numerous interconnected components and interacts with other complex and unpredictable systems such as social, economic, and environmental systems. In Egypt, River Nile flow, precipitation, and groundwater from renewable and nonrenewable aquifers are all examples of freshwater resources $[5,6]$. Egypt also makes use of a variety of low-quality water sources, such as agricultural drainage water and treated residential wastewater. In addition to the non-conventional water resources, desalination is increasingly being utilised to provide household water supply for some places along the Mediterranean and Red Sea coasts $[3,5]$. The most pressing issue in Egypt's water resource management is the disparity between increasing water demand and insufficient water availability [7].

Egypt's agricultural land, which generally consists of the Nile Delta and the narrow valley along the Nile River, is $\sim 4 \%$ of the country's total area. However, it is one of the world's most intensively irrigated areas with highly diversified crop production. Since the current agricultural water use efficiency is generally low, the reuse of return flows collected by agricultural drainage networks and recovering the deep percolation losses by pumping of groundwater have become very important elements of water resources management in Egypt to fill in the gap between the supply and demand [8]. While approximately $80 \%$ of the urban population is connected to public sewerage networks, only $26 \%$ of the rural population receive any sewerage service. The discharge of insufficiently treated industrial/municipal wastewater from some urban centers and inadequate sewerage coverage in rural areas have led to alarming degradation of water quality in the agricultural drainage networks and groundwater aquifers [9]. Consequently, the contaminated water in the Delta poses a significant constraint on water availability and forms a serious health risk through the reuse of drainage water and pumping contaminated groundwater, in addition to polluting the Mediterranean Sea. Local governments, communities, and farmers are aware of this risk and willing to participate in a project reducing pollution in the drains in the Delta $[5,10]$.

The $89.4 \mathrm{~km}$ long El-Salam Canal initiates from the Damietta branch of the River Nile near Damietta city. Along the canal, several drains cross the area and their waters are mixed with those of the canal, such as the Hadous and El-Serw drains that are mixed in a 1:1 ratio [11]. The canal brings the water from the west of the Suez Canal to the east. El-Salam Canal is a part of the north Sinai development project, which is one of the Egypt's largest wasteater reuse projects $[12,13]$. The Egyptian government plans to reclaim 260,400 hectares of desert along Sinai's Mediterranean coast by allowing agricultural drainage water from the Faraskour, El-Serw, and Hadous drains to flow through them $[14,15]$.

To control pollution and enhance water quality, researchers must examine the fluctuation of the levels of heavy metals and other components in both surface and groundwater. Unlike organic pollutants, heavy metals are not biodegradable and tend to accumulate in living organisms, and many heavy metal ions are known to be toxic or carcinogenic $[16,17]$. Heavy metals are those elements with atomic weights of 63.5-200.6, with a specific gravity $>5.0 \mathrm{~g} \mathrm{~cm}^{-3}$ [18]. Heavy metal bioaccumulation in food chains, as well as their toxicity to biological systems as concentrations rise over time, has put great pressure on their separation and purification. Heavy metals are becoming one of the most significant environmental issues as a result of more stringent regulations [19]. Moreover, water quality can be assessed by the concentration and composition of soluble salts (human and livestock drinking, irrigation of crops, etc.). In irrigation waters, salinity, sodicity, and ion toxicity are all important issues. Sodicity or the presence of too much salt, causes the soil structure to 
deteriorate. As a result, monitoring of soils and waterways on a regular basis is necessary to keep track of any changes in salt concentration [20]. Toxicity also refers to the critical concentration of certain salts, such as $\mathrm{CO}_{3}{ }^{2-}, \mathrm{HCO}_{3}{ }^{-}, \mathrm{Cl}^{-}, \mathrm{Na}^{+}, \mathrm{Mg}^{2+}$, and other trace elements, at which such salts have a negative impact on plant development [20].

To measure the water quality status of irrigation water, a water quality index (WQI) is employed, which is a single unitless value distilled from a complex mathematical method based on various hydrochemical properties [21], and well-established indexes including permeability index (PI), Kelley index (KI), potential salinity (PS), etc. [22]. The main objectives of this study are to (i) assess the chemical properties of the El-Salam Canal water at five sites, west of the Suez Canal; (ii) determine the water quality of El-Salam Canal for agriculture irrigation through WQI analysis and evaluation of various agricultural water parameters such as permeability index (PI), residual sodium carbonate (RSC), magnesium hazard $(\mathrm{MH})$, sodium adsorption ratio (SAR), percent sodium $(\mathrm{Na} \%)$, Kelley index (KI), potential salinity (PS), total hardness (TH) and irrigation water quality index (IWQI).

\section{Materials and Methods}

\subsection{Study Area}

The El-Salam Canal, with a total length of $252.75 \mathrm{~km}$, starts from the Damietta Branch (31.3954 N, 31.7690 E) of the River Nile, three km upstream of the Farskour Dam. It consists of two main parts, one part, with a length of $89.75 \mathrm{~km}$, lies to the west of the Suez Canal and is named the El-Salam Canal while the second part, with a length of $163 \mathrm{~km}$, is located to the east of the Suez Canal and is named the El-Sheikh Gaber Canal (Figure 1). These two parts are linked via the $0.77 \mathrm{~km}$ long El-Salam siphon under the Suez Canal [12,13]. Along the El-Salam Canal, drainage water from several drains such as the Bahr El-Baqar, El-Gharbia, Sabal, Elhoks, El-Shakhlouba, Hadous, Elkashaa, Matariya, Ramsis, and El-Serw drains is mixed with the fresh water of the canal [19].

\subsection{Sample Collection and Preparation}

We selected five geographic positions for water sample collection that were chosen using a GPS device (eTrex series, Garmin, Romsey, UK) along the El-Salam Canal, Egypt. These locations correspond to the western end of the Suez Canal, which runs the length of the Manzala Lake, passing through agricultural fields, urban neighbourhoods, fish farms, and industrial zones (Figure 1). The first (S1) station was at the intake of 0.872 billion cubic meters per year of Nile River water from the Damietta branch. The second (S2), third (S3) and fourth (S4) stations were after the mixing points with agricultural drainage water from the Faraskour, El-Serw, and Hadous drains, respectively [23,24], where 0.255, 0.980, and $1.235 \mathrm{BCM}$ /year agricultural drainage water is pumped to canal-18. The fifth station (S5) is located before El-Sahara and $35 \mathrm{~km}$ after the fourth station (S4) (Table 1). The inflow of water from the intake of the River Nile (Damietta branch) is $2.11 \times 10^{9} \mathrm{~m}^{3}$, while the amount of discharged mixed water from the three stations (S2-S4) is $2.11 \times 10^{9} \mathrm{~m}^{3}$ [24].

During the spring of 2020, three surface water samples were taken, where each site's samples were collected at a depth of $15-30 \mathrm{~cm}$ and kept in acid-washed polyethylene bottles for analysis. After that, $0.45 \mu \mathrm{m}$ membrane filters were used to filter the samples. During the collection and treatment of samples, all precautions were taken to reduce the possibility of sample contamination (total samples $=5$ sites $\times 3$ samples $=15$ ). 

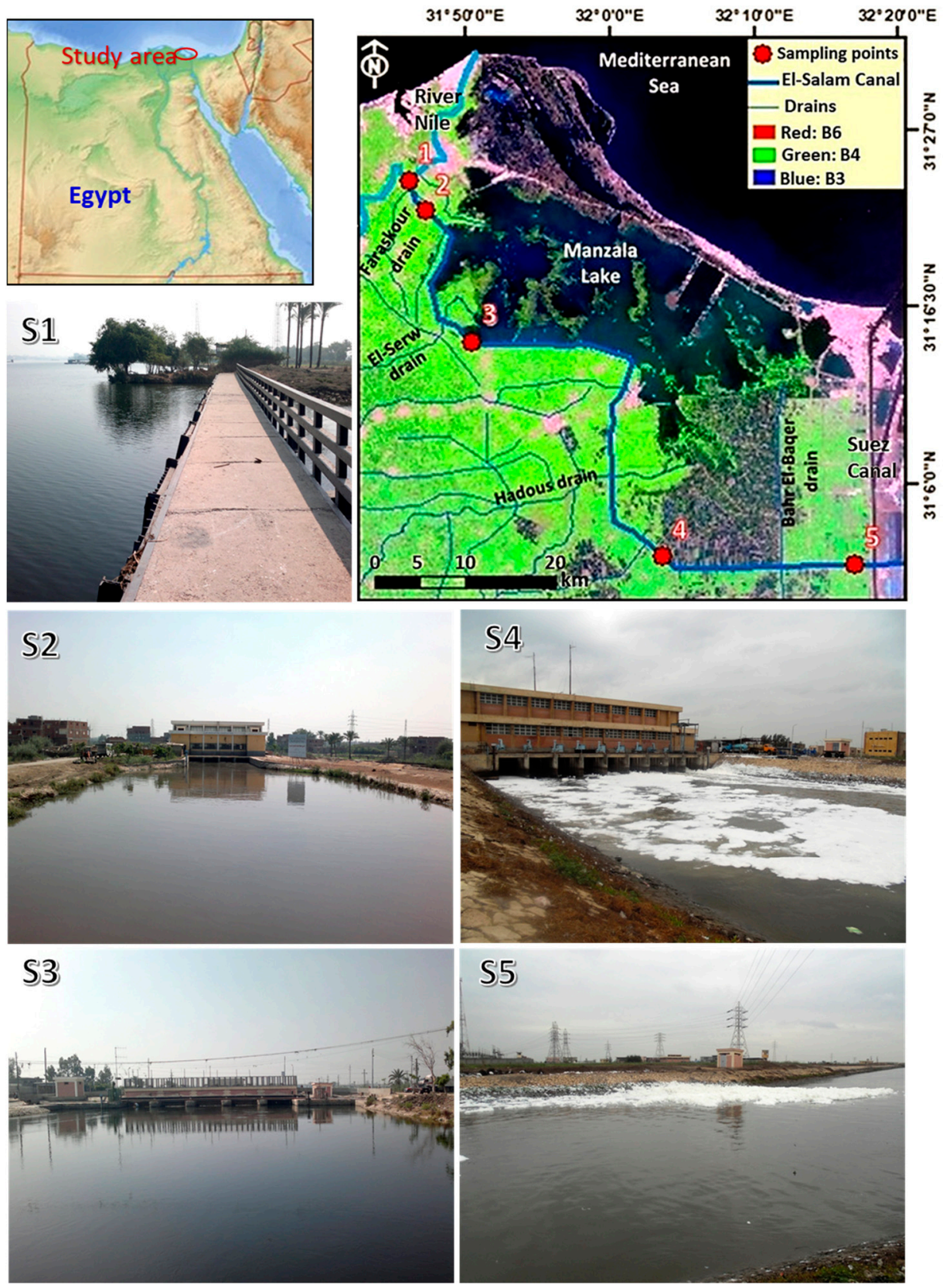

Figure 1. Map of the study area showing different studied sites (S1-S5) along the El-Salam irrigation canal, Egypt. S1 at the intake from the River Nile, S2 located after the mixing with agricultural drainage water from the Faraskour drain, S3 after the El-Serw drain, S4 after the Hadous drain, and S5 before El-Sahara, near the Suez Canal. 
Table 1. Coordinates, inflow, and characterization of the studied sites along the El-Salam Canal, Egypt.

\begin{tabular}{|c|c|c|c|c|}
\hline \multirow{2}{*}{ Sites } & \multirow{2}{*}{ Location } & \multicolumn{2}{|c|}{ Coordinates } & \multirow{2}{*}{ Characterization } \\
\hline & & Latitude (N) & Longitude (E) & \\
\hline S1 & Intake of the canal & 31.3954 & 31.7690 & River Nile (Reference station) \\
\hline $\mathrm{S} 2$ & $\begin{array}{l}\text { After mixing with } \\
\text { Faraskour drain }\end{array}$ & 31.3669 & 31.7890 & Agriculture drain serves about $44.48 \mathrm{~km}^{2}$ \\
\hline S3 & $\begin{array}{l}\text { After mixing with } \\
\text { El-Serw drain }\end{array}$ & 31.2356 & 31.8446 & Agriculture drain serves about $152.8 \mathrm{~km}^{2}$ \\
\hline S4 & $\begin{array}{l}\text { After mixing with } \\
\text { Hadous drain }\end{array}$ & 31.0254 & 32.0672 & $\begin{array}{l}\text { The largest drain in the eastern delta, } \\
\text { serving a total area of } 1756.96 \mathrm{~km}^{2}\end{array}$ \\
\hline S5 & Before El-Sahara & 31.0184 & 32.2882 & End of El-Salam Canal at east Nile Delta \\
\hline
\end{tabular}

\subsection{Field Measurements}

A pH digital meter (Model: YK-2001PH, Lutron, Kuala Lumpur, Malaysia) with a glass electrode previously calibrated with a standard buffered solution at $\mathrm{pH} 7$ was used to measure the $\mathrm{pH}$ of the surface water at each site. A conductivity meter was used to measure electrical conductivity (EC) and total dissolved salts (TDS) (Model: CD-4306, Lutron).

\subsection{Laboratory Measurements}

Sulphate content of the water samples was gravimetrically estimated using $\mathrm{BaCl}_{2}$ solution [25], while $\mathrm{Cl}^{-}$concentration was assessed by a titration method using $\mathrm{AgNO}_{3}$ (N/35.5) [26]. Both carbonates and bicarbonates were also determined by the titration method of Pierce et al. [27]. The concentrations of extractable cations $\left(\mathrm{Na}^{+}\right.$and $\left.\mathrm{K}^{+}\right)$were assessed via flame photometry, using a model PHF 80B Biologie Spectrophotometer (Jenway Company, Felsted, UK), whereas the concentration of $\mathrm{Ca}^{2+}$ and $\mathrm{Mg}^{2+}$ were measured through a model 2380 atomic absorption spectrometer (Perkin-Elmer Company, Jersey City, NJ, USA). The concentration of the nine heavy metals; Fe, Mn, $\mathrm{Zn}, \mathrm{Cu}, \mathrm{Co}, \mathrm{Cr}, \mathrm{Ni}$, $\mathrm{Cd}$, and $\mathrm{Pb}$ was determined according to the APHA standard methodsnumber 3111 [28]. In brief, each sample was filtered and transferred into a separating funnel where its $\mathrm{pH}$ was adjusted to the range from 4.8 to 5.2 , using concentrated $\mathrm{HNO}_{3}$. To each sample, $15 \mathrm{~mL}$ of $1 \%$ ammonium pyrrolidine dithiocarbamate (APDC) and $30 \mathrm{~mL}$ methyl isobutyl ketone (MIBK) were added. The mixture was shaken vigorously for $15 \mathrm{~min}$. Following separation of the phases, the aqueous layer was drawn off into a clean separating funnel and another $30 \mathrm{~mL}$ of MIBK were added, the upper MIBK layer with the extracted metals was retained in the corresponding small $100 \mathrm{~mL}$ separating funnel. The same procedure was repeated three times. The extracted $15 \mathrm{~mL}$ aqueous layer of $2 \mathrm{~N} \mathrm{HNO}_{3}$ containing the chelated metal from the sample solution was kept in tightly stopper scintillating vials for storage until analysis. Heavy metals were measured using the model 2380 atomic absorption spectrometer.

\subsection{Irrigation Water Quality}

The irrigation water suitability is mainly evaluated according to the presence of unwanted dissolved salts or constituents [22]. Permeability index (PI), sodium adsorption ratio (SAR), sodium percent $(\mathrm{Na} \%)$, magnesium hazard $(\mathrm{MH})$, residual sodium carbonate (RSC), total hardness (TH), Kelly's index (KI), potential salinity (PS), irrigation water quality index (IWQI) and its classes are described in Tables 2 and 3. In addition, the water quality indices (WQI) were applied to determine the availability of water in the irrigation systems of surrounded agricultural lands and to evaluate the quality and suitability of these waters (Table S1). The analytical results of different water quality parameters are converted into a single value by the formulas reported in Table 2, while the classes of the WQI are presented in Table 3. 
Table 2. The studied indices for water quality in the El-Salam Canal.

\begin{tabular}{|c|c|c|}
\hline Index & Formula & References \\
\hline Permeability Index (PI) & $\mathrm{PI}=\frac{\left[\mathrm{Na}^{+}+\sqrt{\mathrm{HCO}_{3}^{-}}\right]}{\mathrm{Na}^{+}+\mathrm{Ca}^{2+}+\mathrm{Mg}^{2+}} * 100$ & [29] \\
\hline Sodium Adsorption Ratio (SAR) & $\mathrm{SAR}=\frac{\mathrm{Na}^{+}}{\sqrt{\frac{\mathrm{Ca}^{2+}+\mathrm{Mg}^{2+}}{2}}}$ & {$[30]$} \\
\hline Sodium percent $(\mathrm{Na} \%)$ & $\mathrm{Na} \%=\frac{\mathrm{Na}^{+}+\mathrm{K}^{+}}{\mathrm{Na}^{+}+\mathrm{K}^{+}+\mathrm{Ca}^{2+}+\mathrm{Mg}^{2+}} * 100$ & {$[31]$} \\
\hline Residual Sodium Carbonate (RSC) & $\mathrm{RSC}=\left(\mathrm{CO}_{3}^{2-}+\mathrm{HCO}_{3}^{-}\right)-\left(\mathrm{Ca}^{2+}+\mathrm{Mg}^{2+}\right)$ & [30] \\
\hline Magnesium Hazard (MH) & $\mathrm{MH} \%=\frac{\mathrm{Mg}^{2+}}{\mathrm{Ca}^{2+}+\mathrm{Mg}^{2+}} * 100$ & {$[32,33]$} \\
\hline Total Hardness (TH) & $\mathrm{TH}=\mathrm{Ca}^{2+}+\mathrm{Mg}^{2+}$ & {$[34]$} \\
\hline Kelly's Index (KI) & $\mathrm{KI}=\frac{\mathrm{Na}^{+}}{\mathrm{Ca}^{+}+\mathrm{Mg}^{2+}}$ & {$[35,36]$} \\
\hline Potential Salinity (PS) & $\mathrm{PS}=\mathrm{Cl}^{-}+\frac{1}{2} \mathrm{SO}_{4}^{2-}$ & {$[29,32]$} \\
\hline Irrigation Water Quality Index (IWQI) & $\begin{array}{c}\mathrm{S}_{\mathrm{i}}=\left(\frac{\mathrm{V}_{\text {actual }}-\mathrm{V}_{\text {ideal }}}{\mathrm{V}_{\text {standard }}-\mathrm{V}_{\text {ideal }}}\right) \times 100 \\
\mathrm{RW}_{\mathrm{i}}=\frac{\mathrm{W}_{\mathrm{i}}}{\sum_{\mathrm{i}=1}^{\mathrm{n}} \mathrm{W}_{\mathrm{i}}} \\
\mathrm{W}_{\mathrm{i}}=\frac{1}{V_{\text {standard }}} \\
\mathrm{WQI}=\sum_{\mathrm{i}=1}^{\mathrm{n}} \mathrm{S}_{\mathrm{i}} \times \mathrm{RW}_{\mathrm{i}}\end{array}$ & {$[37,38]$} \\
\hline
\end{tabular}

$\mathrm{W}_{\mathrm{i}}$ is the unit weight of $\mathrm{i}^{\text {th }}$ factors, $S_{\mathrm{i}}$ is permissible limits of $\mathrm{n}^{\text {th }}$ factors.

Table 3. Classes of used indices for water quality and Irrigation water qualities in the present study.

\begin{tabular}{|c|c|c|c|}
\hline Index & Value & Water Quality & References \\
\hline Permeability Index (PI) & $\begin{array}{l}\mathrm{PI}>75 \% \\
\mathrm{PI}=25-75 \% \\
\mathrm{PI}<25 \%\end{array}$ & $\begin{array}{l}\text { Suitable } \\
\text { Moderate } \\
\text { Unsuitable }\end{array}$ & [39] \\
\hline Sodium Adsorption Ratio (SAR) & $\begin{array}{l}\text { SAR }<10 \\
\text { SAR }=10-18 \\
\text { SAR }=19-26 \\
S A R>26\end{array}$ & $\begin{array}{l}\text { Excellent } \\
\text { Good } \\
\text { Doubtful/Fair Poor } \\
\text { Unsuitable }\end{array}$ & {$[30,31]$} \\
\hline Sodium percent $(\mathrm{Na} \%)$ & $\begin{array}{l}\mathrm{Na} \%<20 \\
\mathrm{Na} \%=20-40 \\
\mathrm{Na} \%=40-60 \\
\mathrm{Na} \%=60-80 \\
\mathrm{Na} \%>80\end{array}$ & $\begin{array}{l}\text { Excellent/Safe } \\
\text { Good/Safe } \\
\text { Permissible/Safe } \\
\text { Doubtful/unsafe } \\
\text { Unsuitable/unsafe }\end{array}$ & {$[32,40]$} \\
\hline $\begin{array}{l}\text { Residual Sodium Carbonate (RSC) } \\
\left(\mathrm{meq} \mathrm{L}^{-1}\right)\end{array}$ & $\begin{array}{l}\mathrm{RSC}<1.25 \\
\mathrm{RSC}=1.25-2.50 \\
\mathrm{RSC}>2.50\end{array}$ & $\begin{array}{l}\text { Good } \\
\text { Medium } \\
\text { Unsuitable }\end{array}$ & [40] \\
\hline Magnesium Hazard (MH) & $\begin{array}{l}\mathrm{MH}<50 \% \\
\mathrm{MH}>50 \%\end{array}$ & $\begin{array}{l}\text { Suitable } \\
\text { Unsuitable }\end{array}$ & \\
\hline Kelly's Index (KI) & $\begin{array}{l}\mathrm{KI}<1 \\
\mathrm{KI}>1\end{array}$ & $\begin{array}{l}\text { Suitable } \\
\text { Unsuitable }\end{array}$ & {$[36]$} \\
\hline $\begin{array}{l}\text { Potential Salinity (PS) } \\
\left(\text { meq } L^{-1}\right)\end{array}$ & $\begin{array}{l}\text { PS }<3.0 \\
P S=3.0-5.0 \\
P S>5.0\end{array}$ & $\begin{array}{l}\text { Excellent to good } \\
\text { Good to injurious } \\
\text { Injurious to unsatisfactory }\end{array}$ & [29] \\
\hline $\begin{array}{l}\text { Total Hardness }(\mathrm{TH}) \\
\left(\mathrm{meq} \mathrm{L}^{-1}\right)\end{array}$ & $\begin{array}{l}0-60 \\
61-120 \\
121-180 \\
>181\end{array}$ & $\begin{array}{l}\text { Soft } \\
\text { Moderate } \\
\text { Hard } \\
\text { Very }\end{array}$ & [34] \\
\hline
\end{tabular}


Table 3. Cont.

\begin{tabular}{clll}
\hline Index & \multicolumn{1}{c}{ Value } & \multicolumn{1}{c}{ Water Quality } & References \\
\hline & WQI $=0-25$ & Excellent & Good \\
& WQI $=26-50$ & Poor & {$[37,38]$} \\
Irrigation Water Quality Index (IWQI) & WQI $=51-75$ & Very poor & Unsuitable \\
& WQI $=76-100$ & WQI $>100$ & Con \\
\hline
\end{tabular}

\subsection{Data Treatments}

The data of physicochemical parameters, heavy metal concentrations, and quality indices of the water samples collected from the five sites were submitted to one-way ANOVA followed by Duncan's test to determine the significant difference among the studied sites at a probability level of 0.05 . The ANOVA analysis was carried out using the CosStat software, version 6.311 (CoHort Software, Monterey, CA, USA, http:/ / www. cohort.com, accessed on 1 January 2019). In addition, by using the SPSS software package (Version 27.0. IBM Corp, Armonk, NY, USA), different water parameters and heavy metals from five locations were tested to Pearson's correlation. Moreover, the data of water chemical parameters and heavy metals were subjected to principal component analysis (PCA) using the PAST program (multivariate statistical package, ver. 1.72, Oslo, Norway, http:/ / www.nhm.uio.no/ ohammer/past/plot.html, accessed on 1 January 2019). The piper plot was performed using AquaChem program (2014, ver. 5.1) based on the data of cations and anions. While Doneen [29], Wilcox [31], and US salinity Richards [30] diagrams were used for plotting and classifying the sampled sites.

\section{Results and Discussion}

\subsection{Water Characteristics}

\subsubsection{Chemical Composition}

The results of the hydrochemical characteristic of surface water samples S1 to S5, collected from five sites along the El-Salam Canal are listed in Table 4. The $\mathrm{pH}$ varied from 7.78 in S5 to 8.42 in S4, with a mean value of 8.02, demonstrating the alkaline nature of the waters. Variations in conductivity and bicarbonate concentration are linked to $\mathrm{pH}$ variations [41]. The EC also displays wide variations, ranging in value from 0.72 to $2.34 \mathrm{~d} \mathrm{Sm}^{-1}$. The EC value may be an approximate index of the overall amount of dissolved substances in water, such as salts. Temperature, concentration, and the sorts of ions present all influence the results [42]. The sites S3, S4, and S5 recorded EC values above the acceptable permissible limit of $1.5 \mathrm{~d} \mathrm{Sm}^{-1}$ [43]. The total dissolved solids (TDS) show wide variations, ranging between 292.00 to $1124.00 \mathrm{mg} \mathrm{L}^{-1}$ with a mean concentration of $852.60 \mathrm{mg} \mathrm{L}^{-1}$.

The contents of major ions govern the basic hydrochemical properties of surface water [44]. Except for $\mathrm{Cl}^{-}$and $\mathrm{HCO}_{3}{ }^{-}$, the mean levels of all ions in water samples are above the WHO [43] guidelines, as indicated in Table 4 . The sequence of main cations in surface water were $\mathrm{Na}^{+}(220.72)>\mathrm{Ca}^{2+}(161.14)>\mathrm{Mg}^{2+}(92.90)>\mathrm{K}^{+}$(35.95). 
Table 4. Physicochemical characteristics of water samples collected from different sites (S1-S5) along the El-Salam Canal.

\begin{tabular}{|c|c|c|c|c|c|c|c|c|c|c|c|}
\hline \multirow{2}{*}{ Sites } & \multirow{2}{*}{$\mathrm{pH}$} & \multirow{2}{*}{$\begin{array}{c}\mathrm{EC} \\
\mathrm{dS} \mathrm{m}^{-1}\end{array}$} & TDS & $\mathrm{Na}^{+}$ & $\mathrm{K}^{+}$ & $\mathrm{Ca}^{2+}$ & $\mathrm{Mg}^{2+}$ & $\mathrm{Cl}^{-}$ & $\mathrm{SO}_{4}{ }^{2-}$ & $\mathrm{CO}_{3}{ }^{2-}$ & $\mathrm{HCO}_{3}{ }^{-}$ \\
\hline & & & \multicolumn{8}{|c|}{$\mathrm{mg} \mathrm{L}^{-1}$} & \\
\hline S1 & 7.82 & 0.72 & 292.00 & 71.88 & 29.56 & 115.19 & 65.19 & 54.54 & 384.92 & 0.00 & 122.73 \\
\hline $\mathrm{S} 2$ & 7.94 & 0.97 & 895.00 & 135.46 & 32.69 & 126.59 & 88.66 & 67.54 & 657.24 & 0.03 & 192.24 \\
\hline S3 & 8.12 & 2.24 & 1098.00 & 171.54 & 39.56 & 137.21 & 97.07 & 73.43 & 763.74 & 0.06 & 205.96 \\
\hline $\mathrm{S} 4$ & 8.42 & 2.34 & 1124.00 & 371.55 & 37.60 & 193.32 & 82.48 & 131.18 & 991.84 & 0.01 & 346.30 \\
\hline S5 & 7.78 & 2.1 & 854.00 & 353.16 & 40.34 & 233.40 & 131.10 & 240.03 & 1144.22 & 0.00 & 315.79 \\
\hline Mean & 8.02 & 1.67 & 852.60 & 220.72 & 35.95 & 161.14 & 92.90 & 113.34 & 788.39 & 0.02 & 236.61 \\
\hline$\pm \mathrm{SE}$ & 0.05 & 0.15 & 67.08 & 26.86 & 0.93 & 10.07 & 4.87 & 15.33 & 59.04 & 0.01 & 18.49 \\
\hline $\mathrm{CV} \%$ & 3.26 & 45.80 & 39.34 & 60.84 & 12.93 & 31.24 & 26.21 & 67.65 & 37.44 & 127.48 & 39.07 \\
\hline $\mathrm{LSD}_{0.05}$ & $2.58 *$ & 0.14 * & $3.18 *$ & $5.79 *$ & $1.72 *$ & $6.8^{*}$ & $2.63 *$ & $3.92 *$ & $10.28 *$ & $0.82 *$ & $5.47 *$ \\
\hline \multicolumn{12}{|c|}{ Permissible limits worldwide } \\
\hline WHO [43] & $6.5-8.5$ & 1.5 & 500 & 200 & 12 & 75 & 50 & 250 & 250 & - & 500 \\
\hline FAO [45] & $6.5-8.5$ & $0.7-<3$ & $0-2000$ & $0-920$ & $0-2$ & $0-400$ & $9.4-13.5$ & 70 & 575 & - & - \\
\hline
\end{tabular}

SE: Standard error; CV: Coefficient of variation, Permissible limits are those provided by Food and Agriculture Organization (FAO) for irrigation water and World Health Organization (WHO); ${ }^{*}$ significant at $p \leq 0.05$.

Around $60 \%$ of the TDS is made up of major cations. The most common cations are sodium and calcium, which account for $43 \%$ and $32 \%$ of TDS, respectively. Some $\mathrm{Na}^{+}$ concentrations, but none of the $\mathrm{K}^{+}$concentrations, are under the WHO [43] permissible limits of 200 and $12 \mathrm{mg} \mathrm{L}^{-1}$, respectively. $\mathrm{K}^{+}$levels that are too high might cause magnesium insufficiency and iron chlorosis. In addition, divalent cations $\left(\mathrm{Ca}^{2+}\right.$ and $\left.\mathrm{Mg}^{2+}\right)$ have all their concentrations are higher than the WHO [43] acceptable limits of 75 and $50 \mathrm{mg} / \mathrm{L}^{-1}$, respectively. The sequence of major anions in surface water were $\mathrm{SO}_{4}{ }^{2-}$ $\left(788.39 \mathrm{mg} \mathrm{L}^{-1}\right)>\mathrm{HCO}_{3}{ }^{-}\left(236.61 \mathrm{mg} \mathrm{L}^{-1}\right)>\mathrm{Cl}^{-}\left(113.34 \mathrm{mg} \mathrm{L}^{-1}\right)>\mathrm{CO}_{3}{ }^{2-}\left(0.02 \mathrm{mg} \mathrm{L}^{-1}\right)$. Sulphate and bicarbonate are the dominant dissolved ion, it accounts for $69 \%$ and $22 \%$ of the total anions, respectively (Table 4). The $\mathrm{SO}_{4}{ }^{2-}$ and $\mathrm{HCO}_{3}{ }^{-}$values of water samples varied in a wide range of 348.92-1144.22 and $122.73-346.30 \mathrm{mg} \mathrm{L}^{-1}$ with mean values of 788.39 and $236.61 \mathrm{mg} \mathrm{L}^{-1}$, respectively. The $\mathrm{SO}_{4}{ }^{2-}$ and $\mathrm{HCO}_{3}{ }^{-}$values are all over the WHO's recommended limits of 250 and $500 \mathrm{mg} \mathrm{L}^{-1}$ [42]. $\mathrm{SO}_{4}{ }^{2-}$ salts damage sensitive crops by restricting calcium absorption while increasing sodium and potassium adsorption, causing a disruption in the plant's cationic balance. The concentration of chloride varies between 54.54 and $240.03 \mathrm{mg} \mathrm{L}^{-1}$ (mean value $=113.34 \mathrm{mg} \mathrm{L}^{-1}$ ) and contributes $9 \%$ of the total anionic concentration in the equivalent unit. All of the $\mathrm{Cl}^{-}$concentrations are within the WHO [43] acceptable limits of $250 \mathrm{mg} \mathrm{L}^{-1}$. For the least abundant anion, $\mathrm{CO}_{3}{ }^{2-}$ concentration ranges from 0 to $0.06 \mathrm{mg} \mathrm{L}^{-1}$. These cations and anions showed an increasing trend from S1 (the intake of the canal) to S5 (before El-Sahara) of the El-Salam Canal. This may be due to the mixing of wastewater from the Faraskour, El-Serw, and Hadous drains with El-Salam Canal water at the pump stations. The coefficient of variation $(\mathrm{CV})$ is the percent standard deviation of each element in relation to its average value and reflects the degree of variability with respect to the metal concentrations $(51 \% \leq \mathrm{CV} \leq$ $100 \%$ high; moderate; CV $>100 \%$; CV $\leq 20 \%$, low; $21 \% \leq \mathrm{CV} \leq 50 \%$, is exceptionally high variability) [46]. The results revealed that all ions had $\mathrm{CVs}$ more than $10 \%$, with $\mathrm{CO}_{3}{ }^{2-}$ having a CV of almost $100 \%$; in particular, $\mathrm{CO}_{3}{ }^{2-}$ has a $\mathrm{CV}$ of above $100 \%$, which indicated strong spatial variability, showing that these ions are sensitive variables that change with the ecosystem [44].

\subsubsection{Hydrochemical Facies}

The primary chemical compositions in three parts of a ternary diagram are plotted in a Piper plot to illustrate the chemistry of a rock, soil, or water sample. The one on the left depicts cations, while the one on the right depicts anions with a diamond-shaped area to depict a combined location of cations and anions. The dominating cations and anions that 
impact the hydrochemistry of groundwater are described by hydrochemical facies, which are different zones [47-49]. The diamond-shaped area of the Piper diagram is divided into four major parts, each part representing and explaining a particular type of variation or domination of cations and anions (Figure 2).
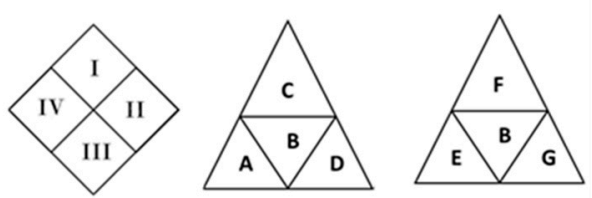

$$
\begin{aligned}
& \text { A. Calcium type } \\
& \text { B. No dominant type } \\
& \text { C. Magnesium type } \\
& \text { D. Sodium type } \\
& \text { E. Bicarbonate type } \\
& \text { F. Sulfate type } \\
& \text { G. Chloride type }
\end{aligned}
$$

The diamond-shaped area

$\mathrm{GI} \mathrm{SO}_{4} \cdot \mathrm{Cl}-\mathrm{Ca} \cdot \mathrm{Mg}$

$\mathrm{GII} \mathrm{SO}_{4} \cdot \mathrm{Cl}-\mathrm{Na}$

GIII $\mathrm{HCO}_{3}$. Na

GIV $\mathrm{HCO}_{3}-\mathrm{Ca} \cdot \mathrm{Mg}$

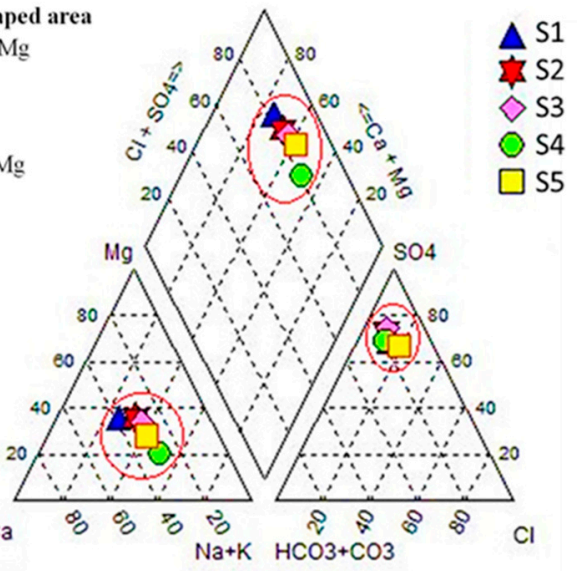

Figure 2. Piper plot of the studied five sites at El-Salam Canal for the hydrogeochemical characteristics of water.

According to such a diagram, water can be assessed in one type: $\mathrm{SO}_{4} \cdot \mathrm{Cl}-\mathrm{Ca} \cdot \mathrm{Mg}$ type (mixed type) was the dominant water type in four sites; moreover, one site (S4) was $\mathrm{SO}_{4}$. $\mathrm{Cl}$ $\mathrm{Na}$ type. Overall, ion exchange, evaporation, and concentration affected the hydrochemical surfaces of five sites of water sample [50,51]. With respect to major anions, water belonging to $\mathrm{SO}_{4}{ }^{-}$-dominant (Figure 2). The highest $\mathrm{Cl}^{-}$concentrations are found at the sites of $\mathrm{S} 2$ and S3. Regarding the major cations, the water had no dominant type except for at S4 where it was Na-dominant.

\subsubsection{Heavy Metals Assessment}

The mean concentrations of $\mathrm{Fe}, \mathrm{Mn}, \mathrm{Pb}, \mathrm{Cu}, \mathrm{Co}, \mathrm{Ni}, \mathrm{Cr}, \mathrm{Cd}$, and $\mathrm{Zn}$ in the surface water samples collected along the canal are shown in Table 5 . The mean concentration of the measured metals in water was found to be in the following order (in $\left.\mathrm{mgL}^{-1}\right): \mathrm{Zn}(0.258)$ $<\mathrm{Cd}(0.582)<\mathrm{Cr}(0.865)<\mathrm{Ni}(1.403)<\mathrm{Fe}(1.500)<\mathrm{Mn}(1.674)<\mathrm{Co}(3.626)<\mathrm{Cu}(4.560)<$ $\mathrm{Pb}$ (5.849). Generally, most of the metals had a higher concentration at site $\mathrm{S} 4 \mathrm{for} \mathrm{Cr}, \mathrm{Ni}$, $\mathrm{Co}$, and S5 for Zn, Cd, Mn. This canal receives large amounts of agricultural drainage and sewage as well as industrial wastewater, rendering it unfit for human use until it is treated. Anthropogenic activities cause a rise in heavy metal levels in eco-systems, increasing pollution and putting human health at risk $[19,52]$. 
Table 5. Heavy metal concentrations in water samples of the different sites (S1-S5) along the El-Salam Canal, Egypt.

\begin{tabular}{|c|c|c|c|c|c|c|c|c|c|}
\hline \multirow{2}{*}{ Sites } & $\mathbf{F e}$ & Mn & $\mathrm{Pb}$ & $\mathrm{Cu}$ & Co & $\mathbf{N i}$ & $\mathrm{Cr}$ & $\mathrm{Cd}$ & $\mathrm{Zn}$ \\
\hline & \multicolumn{9}{|c|}{$\mathrm{mg} \mathrm{L}^{-1}$} \\
\hline S1 & 0.875 & 0.688 & 4.660 & 2.330 & 0.354 & 0.274 & 0.179 & 0.051 & 0.212 \\
\hline S2 & 1.610 & 1.950 & 7.730 & 5.030 & 3.471 & 1.447 & 0.882 & 0.087 & 0.017 \\
\hline S3 & 1.861 & 1.770 & 6.480 & 6.440 & 4.675 & 1.724 & 1.020 & 0.224 & 0.353 \\
\hline $\mathrm{S} 4$ & 1.714 & 0.960 & 5.274 & 4.120 & 5.594 & 2.045 & 1.474 & 0.479 & 0.229 \\
\hline S5 & 1.440 & 3.000 & 5.100 & 4.880 & 4.037 & 1.525 & 0.772 & 2.070 & 0.479 \\
\hline Mean & 1.500 & 1.674 & 5.849 & 4.560 & 3.626 & 1.403 & 0.865 & 0.582 & 0.258 \\
\hline$\pm \mathrm{SE}$ & 0.076 & 0.182 & 0.250 & 0.300 & 0.398 & 0.134 & 0.094 & 0.170 & 0.034 \\
\hline CV\% & 25.44 & 54.48 & 21.36 & 32.94 & 54.93 & 47.90 & 54.03 & 145.74 & 66.83 \\
\hline $\mathrm{LSD}_{0.05}$ & $1.47^{*}$ & $1.37^{*}$ & $2.65 *$ & $1.27 *$ & $0.08^{*}$ & $0.05^{*}$ & $0.98 *$ & $0.03 *$ & 0.008 * \\
\hline \multicolumn{10}{|c|}{ Permissible limits worldwide } \\
\hline US EPA [53] & 5 & 0.2 & 5 & 0.2 & 0.05 & 0.2 & 0.1 & 0.01 & 2 \\
\hline EU [54] & 0.2 & 0.05 & - & 0.2 & - & 0.02 & 0.05 & 0.005 & - \\
\hline
\end{tabular}

SE: standard error; CV: coefficient of variation, EU: European Union Standard, US EPA: United States Environmental Protection. Agency, * significant at $p \leq 0.05$.

Furthermore, several authors discovered a correlation between heavy metal concentrations in water and the amount of organic matter and extractable carbonate fraction $[55,56]$. Our findings revealed that S1 (the canal inlet) appeared to be the cleanest part of the lake, with the lowest amounts of the metals tested. Agricultural, industrial, and sewage drains are unlikely to have polluted this location much. To assess the potential adverse biological effects and water toxicity of the water, a comparison with EU [54] and US EPA [53] with present results was done. According to the US EPA [53], Fe and Zn levels in El-Salam Canal are within the permissible limit recommended for drinking and irrigation purposes, while $\mathrm{Mn}, \mathrm{Pb}, \mathrm{Cu}, \mathrm{Co}, \mathrm{Ni}, \mathrm{Cr}$, and $\mathrm{Cd}$ were found in higher concentrations than those reported by Dang, et al. [57], where they emphasized that the largest portion of trace elements accumulated in sediments can return to natural water systems in suspended or dissolved form and pose a potential risk for the aquatic environment.

\subsubsection{Correlation between Water Chemical Parameters and Heavy Metals}

A Pearson correlation matrix was used to investigate their influence on heavy metal dynamics in the water body. (Table S2). The strength of a relationship between any two variables may be estimated using correlation analysis [58]. In an aquatic system, salinity can reflect the effect of terrestrial inputs to a certain degree in the water streams [59]. Salinity was positively correlated to $\mathrm{Na}^{+}, \mathrm{K}^{+}, \mathrm{Cl}^{-}$, and $\mathrm{SO}_{4}{ }^{2-}$ with values of $\mathrm{r}=0.984$, $0.940,0.860$, and 0.871 , respectively. TDS showed positive correlation with $\mathrm{Cr}, \mathrm{Fe}, \mathrm{Co}$ and $\mathrm{Ni}$ with value of $\mathrm{r}=0.938,0.980,0.980$ and 0.985 , respectively (Table S2). Multiple variables impacted the concentration, distribution, and movement of heavy metals throughout the estuary, including $\mathrm{pH}$, temperature, $\mathrm{DO}$, salinity, and the mixing process of freshwater with saline water $[60,61]$.

In the El-Salam Canal water, the major exchangeable ions showed significant correlations with many cations and anions (Table S2). Na-HCO $3, \mathrm{Na}-\mathrm{Ca}$, and $\mathrm{Na}-\mathrm{SO}_{4}$ showed a significant positive correlation with values of $\mathrm{r}=0.992,0.939$, and 0.948 , respectively. $\mathrm{Ca}-\mathrm{SO}_{4}, \mathrm{Ca}-\mathrm{HCO}_{3}, \mathrm{Ca}-\mathrm{Cl}$ and $\mathrm{Ca}-\mathrm{Cd}$ showed positive correlation with value of $\mathrm{r}=0.941$, $0.900,0.970$ and 0.903 , respectively. $\mathrm{Mg}-\mathrm{Mn}, \mathrm{Mg}-\mathrm{Cd}$, and $\mathrm{Mg}-\mathrm{Cl}$ were positively correlated with values of $\mathrm{r}=0.953,0.886$, and 0.979 , respectively. While major anions $\mathrm{SO}_{4}-\mathrm{HCO}_{3}$ showed a positive correlation $(\mathrm{r}=0.944)$. Adams, et al. [62] found that $\mathrm{Na}, \mathrm{Ca}$, and $\mathrm{Mg}$ are related to salinity and main elements, which is consistent with our findings.

Different correlations between dissolved metals and some of them result from various behaviors, and/or different sources and/or sinks of metals. Fe showed a significant positive correlation with $\mathrm{Co}$ and $\mathrm{Ni}(\mathrm{r}=0.922$ and 0.932 , respectively). Co showed a 
positive correlation with $\mathrm{Cr}$ and $\mathrm{Ni}$ with values of $\mathrm{r}=0.957$ and 0.997 , respectively. $\mathrm{Ni}$ was a positive correlation with $\mathrm{Cr}$ with values of 0.958 . In contrast to our results, Zhang, et al. [63] and El-Amier, et al. [19] found a negative correlation between heavy metals and salinity. Despite the fact that $\mathrm{pH}$ is thought to be a critical parameter determining metal availability [64], the current results showed no significant correlation between $\mathrm{pH}$ and the investigated heavy metals. In this context, Dragović, et al. [65] showed that $\mathrm{Cd}, \mathrm{Cr}, \mathrm{Cu}, \mathrm{Mn}$, $\mathrm{Ni}, \mathrm{Pb}$, and $\mathrm{Zn}$ are not correlated with the $\mathrm{pH}$.

To correlate the heavy metals with the studied sites, PCA was performed as shown in Figure 3. It is clear that sites S1 and S2 were segregated on the left side where they showed no positive correlation with any heavy metals. However, sites S3 and S4 were separated on the right side of the plot and they showed a close correlation to $\mathrm{Fe}, \mathrm{Cu}, \mathrm{Ni}, \mathrm{Cr}, \mathrm{Co}, \mathrm{TDS}$, and $\mathrm{pH}$ (Figure 3). On the other side, right lower of the plot, site 5 was separated alone and showed a correlation with $\mathrm{Cd}, \mathrm{Zn}, \mathrm{Mn}, \mathrm{Na}^{+}, \mathrm{Mg}^{2+}, \mathrm{Ca}^{2+}$, and $\mathrm{Cl}^{-}$. These results showed that by going away from the inlet (i.e the Nile) the water becomes more contaminated with the heavy metals, due to the mixing of the irrigation water with the drainage water from the agricultural drains (Faraskour, El-Serw, and Hadous drains).

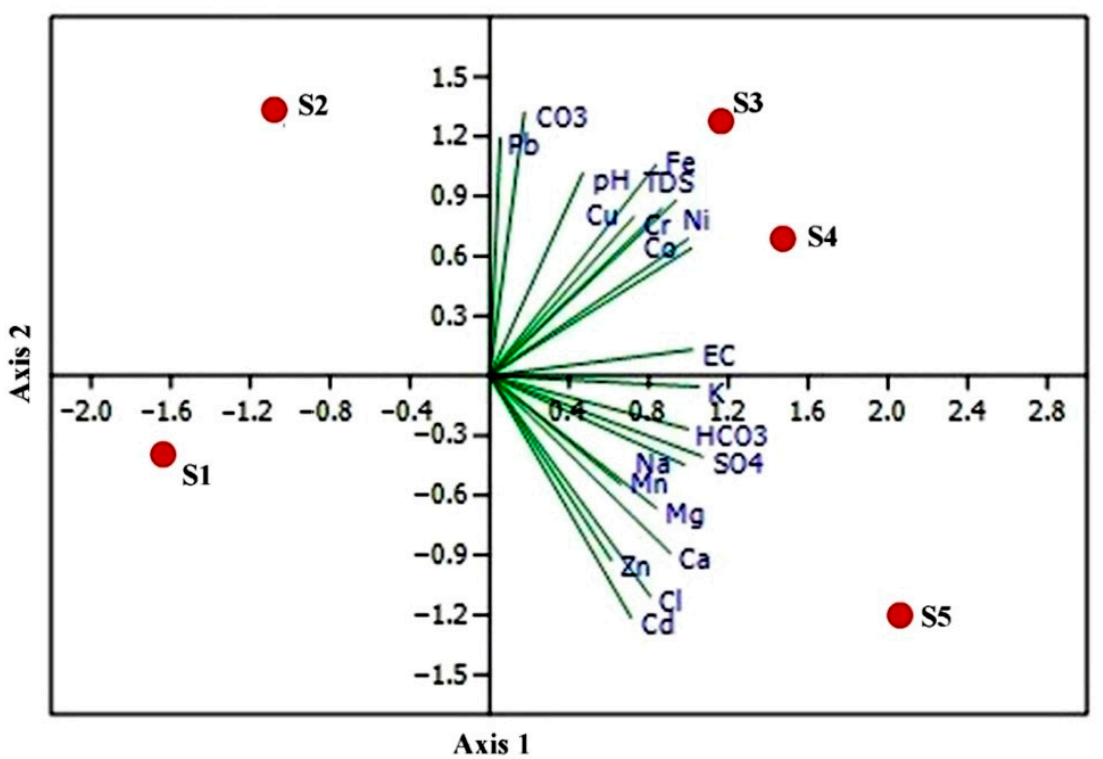

Figure 3. Principal component analysis (PCA) of the water chemical parameters and heavy metals from the five studied sites (S1-S5) along the El-Salam Canal, Egypt.

\subsection{Irrigation Suitability Assessment}

\subsubsection{Permeability Index (PI)}

Doneen [29] proposed a categorization system for irrigation water based on PI. This takes into account the $\mathrm{Na}^{+}, \mathrm{Ca}^{2+}, \mathrm{Mg}^{2+}$, and $\mathrm{HCO}_{3}{ }^{-}$concentration of the soil. Figure 4 and Table 6 demonstrate that the PI values in the study area range from 32.89 percent in S1 to 60.27 percent in S4. Based on Doneen's chart classification, water samples with PI greater than $75 \%$ (PI $>75 \%)$ are termed suitable, moderate $(25-75 \%)$ and unsuitable $(<25 \%)[29,66]$. The PI is also used to reflect the applicability of water for irrigation purposes [38]. 


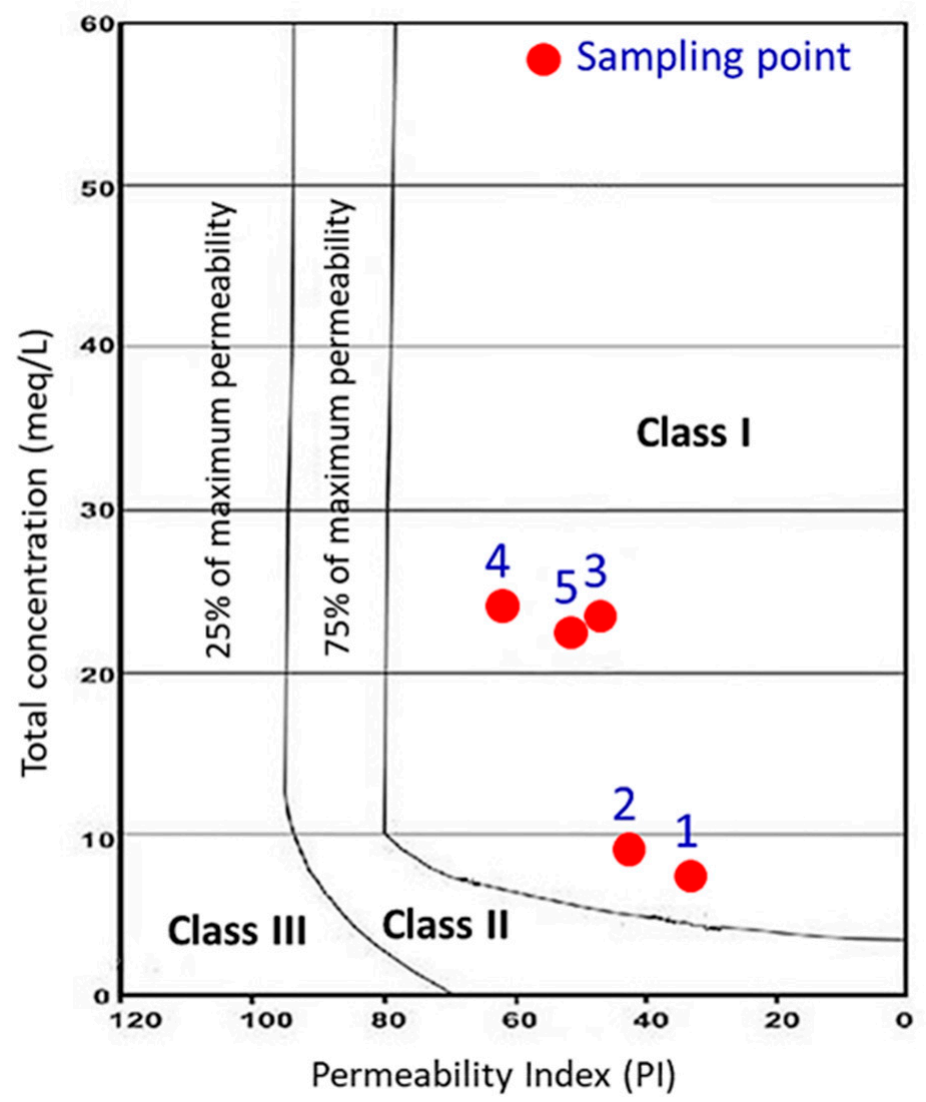

Figure 4. The classification of Doneen [29] of the irrigation water of the five sampling sites stations based on the permeability index (PI).

Table 6. Water indices result of water samples collected from different sites (S1-S5) along the El-Salam Canal.

\begin{tabular}{|c|c|c|c|c|c|c|c|c|c|}
\hline Sites & $\begin{array}{c}\text { PI } \\
(\%)\end{array}$ & SAR & KI & $\begin{array}{c}\text { MH } \\
(\%)\end{array}$ & $\begin{array}{l}\mathrm{Na} \\
(\%)\end{array}$ & $\begin{array}{c}\text { PS } \\
\left(\text { meq L }^{-1}\right)\end{array}$ & $\begin{array}{c}\text { RSC } \\
\left(\text { meq L }^{-1}\right)\end{array}$ & $\begin{array}{c}\text { TH } \\
\left(\text { meq L }^{-1}\right)\end{array}$ & IWQI \\
\hline S1 & 32.89 & 7.57 & 0.40 & 36.14 & 35.99 & 5.54 & -9.10 & 11.11 & 40.26 \\
\hline S2 & 42.58 & 13.06 & 0.63 & 41.19 & 43.86 & 8.74 & -10.46 & 13.61 & 56.46 \\
\hline S3 & 45.81 & 15.85 & 0.73 & 41.43 & 47.40 & 10.01 & -11.46 & 14.84 & 82.04 \\
\hline S4 & 60.27 & 31.64 & 1.35 & 29.91 & 59.73 & 14.01 & -10.76 & 16.43 & 114.82 \\
\hline S5 & 51.69 & 26.16 & 0.97 & 35.97 & 51.91 & 18.67 & -17.26 & 22.44 & 96.23 \\
\hline Mean & 46.65 & 18.85 & 0.82 & 36.93 & 47.78 & 11.40 & -11.81 & 15.69 & 77.96 \\
\hline$\pm \mathrm{SE}$ & 2.04 & 1.97 & 0.07 & 0.94 & 1.77 & 1.01 & 0.63 & 0.85 & 5.99 \\
\hline $\mathrm{LSD}_{0.05}$ & $6.49 *$ & 5.95 * & $1.15^{*}$ & $6.56 *$ & $7.33 *$ & $1.23 *$ & $1.17^{*}$ & $1.64 *$ & 3.05 * \\
\hline
\end{tabular}

PI: permeability index, SAR: sodium adsorption ratio, KI: Kelly's index, MH: magnesium hazard, PS: potential salinity, RSC: residual sodium carbonate, TH: total hardness, SE: standard error. ${ }^{*}$ significant at $p<0.05$.

Based on PI values, all of the samples in this study had moderate PI levels and are therefore considered acceptable for irrigation (Table 7). High PI values are associated with high amounts of $\mathrm{Na}^{+}$and $\mathrm{HCO}^{3-}$, which may be due to carbonate dissolution and cation exchange in minerals like calcite and dolomite [67]. 
Table 7. Classification of water for irrigation based on different parameters and indexes.

\begin{tabular}{|c|c|c|c|c|c|c|c|c|c|}
\hline Sites & PI & SAR & KI & MH & $\mathrm{Na}$ & PS & RSC & TH & IWQI \\
\hline S1 & Moderate & Excellent & Suitable & Suitable & Good/Safe & $\begin{array}{l}\text { Injurious to } \\
\text { unsatisfactory }\end{array}$ & Good & Soft & Good \\
\hline S2 & Moderate & Good & Suitable & Suitable & Permissible/Safe & $\begin{array}{l}\text { Injurious to } \\
\text { unsatisfactory }\end{array}$ & Good & Soft & Poor \\
\hline S3 & Moderate & Good & Suitable & Suitable & Permissible/Safe & $\begin{array}{l}\text { Injurious to } \\
\text { unsatisfactory }\end{array}$ & Good & Soft & Very poor \\
\hline S4 & Moderate & Unsuitable & Unsuitable & Suitable & Permissible/Safe & $\begin{array}{l}\text { Injurious to } \\
\text { unsatisfactory }\end{array}$ & Good & Soft & Unsuitable \\
\hline S5 & Moderate & Unsuitable & Suitable & Suitable & Permissible/Safe & $\begin{array}{l}\text { Injurious to } \\
\text { unsatisfactory }\end{array}$ & Good & Soft & Very poor \\
\hline
\end{tabular}

PI: permeability index, SAR: sodium adsorption ratio, KI: Kelly's index, MH: magnesium hazard, PS: potential salinity, RSC: residual sodium carbonate, TH: total hardness.

\subsubsection{Sodium Percentage $(\mathrm{Na} \%)$}

The soluble sodium concentration of surface water is measured in Na percent, which is also used to assess Na hazard. Because sodium interacts with the soil to reduce permeability, Na percent is a frequent measure used to assess the suitability of natural waters for irrigation [31]. According to Fipps [68], water with a Na\% content more than $60 \%$ might produce sodium accumulations, which can lead to a breakdown in the physical characteristics of the soil. Alkali soils are created when excess $\mathrm{Na} \%$ combines with carbonate, whereas saline soils are formed when sodium combines with chloride. The $\% \mathrm{Na}$ of the surface waters in the study area ranges from $35.97 \%$ in $\mathrm{S} 1$ to $59.73 \%$ in $\mathrm{S} 4$ with a mean value of $47.78 \%$ (Table 6). Therefore, according to Eaton [40] and Ravikumar, et al. [32], the sampling sites of the El-Salam Canal are good/safe for S1, S2, and S3 sites and permissible/safe for S4 and S5 sites (Table 7).

The Wilcox [31] diagram relating sodium percent and EC shows that $20 \%$ of the water samples fall in the "excellent to good" range (S1; intake of the canal), 20\% after mixing with Faraskour drain (S2) fall within the "Good to Permissible" range. While the remaining 60\% fall under the "doubtful to unsuitable" range (Figure 5a).

a)

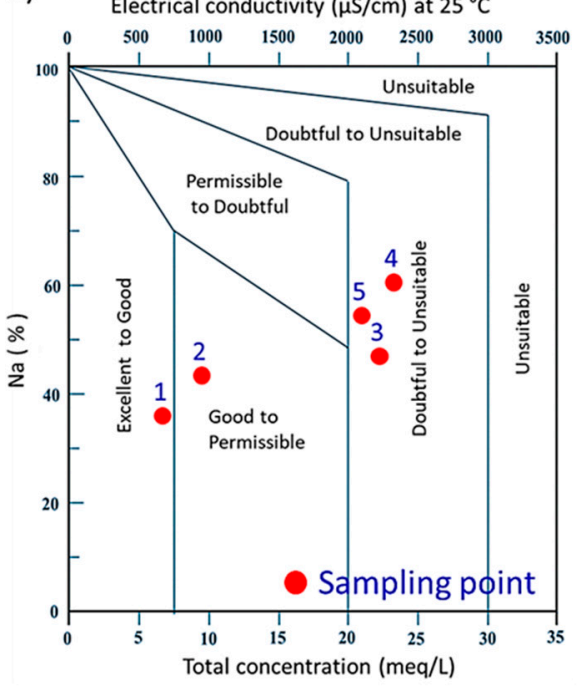

b)

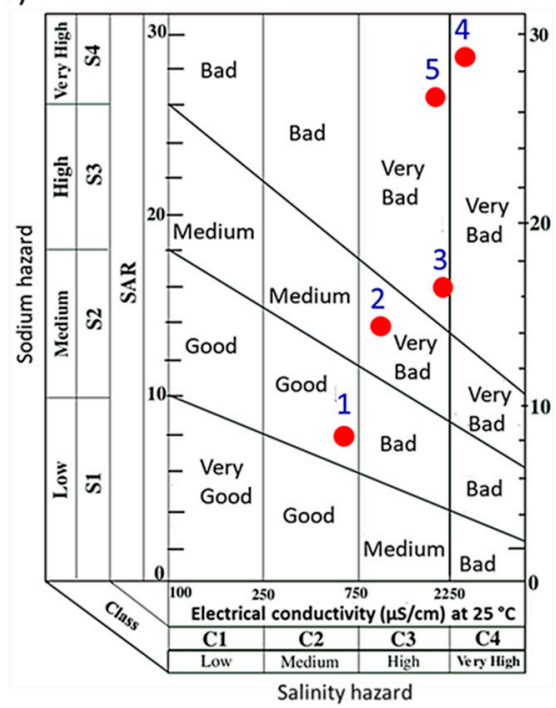

Figure 5. Suitability of water quality from the five sampling sites for irrigation purposes based on (a) The Wilcox diagram [31] and (b) US salinity diagram indicate the ratio of SAR versus EC $\left(\mu \mathrm{S} \mathrm{cm}{ }^{-1}\right)$ [30]. 
This makes the water in the study area after the second pump (after mixing with El-Serw drain waters) need treating before mixing it with water in the El-Salam Canal so that it is suitable for irrigation purposes.

\subsubsection{Sodium Adsorption Ratio (SAR)}

Because of sodium's effects on the soil, irrigation water with high levels of salt is of special concern and creates a sodium hazard. The SAR also characterises sodium risks, which can impair soil permeability and hence prevent crops from absorbing water [48]. Sodium is absorbed by soil particles and gets linked to them. When the soil is dry, it hardens and compacts, becoming increasingly resistant to water penetration. Fine-textured soils, particularly those with high clay content, are the most vulnerable to this activity. To maintain soils with high SARs, certain amendments may be necessary. $\mathrm{Ca}^{2+}$ and $\mathrm{Mg}^{2+}$, if present in sufficient amounts in the soil, will counteract the effects of $\mathrm{Na}^{+}$and help the maintenance of healthy soil properties $[68,69]$. SAR is used to classify surface water into the following categories: excellent (SAR $<10)$, good $(10<$ SAR $<18)$, doubtful $(18<$ SAR $<26$ ), and unsuitable (SAR $>26$ ). SAR of water samples varied from 7.57 to 26.16 with a mean of 18.85 (Table 6). Therefore, according to Wilcox [31] and Richards [30], the sampling sites of the El-Salam Canal are excellent for S1 (intake of the canal), good for S2 and S3, but unsuitable for S4 and S5 (Table 7).

Using a US Salinity Laboratory (USSL) diagram to plot the SAR versus the EC provides more information into the suitability of water for irrigation [30]. Figure $5 b$ shows that about $20 \%$ of the water samples are of medium salinity/medium sodium type (C2-S2, suitable for irrigation; S1), 20\% are of high salinity/high sodium type (C3-S3, not suitable for irrigation; S2), and 40\% are of high salinity/very high sodium type (C3-S3, not suitable for irrigation; S2) (C3-S4, suitable for irrigation; S3 and S5) and 20\% fall under very high salinity /very high sodium type of water (C4-S4, not suitable for irrigation; S4). Therefore, most of the drains water needs to be treated before mixing it with water in the El-Salam Canal, which reduces salinity.

\subsubsection{Kelly's Index (KI)}

Kelly [36] proposed Kelly's index as an essential measure in the evaluation of irrigation water quality. The $\mathrm{Na}, \mathrm{Ca}$, and $\mathrm{Mg}$ levels in the water are used to calculate this value. Water with a KI value more than one $(\mathrm{KI}>1)$ is deemed unfit for irrigation, whereas water with a $\mathrm{KI}$ value less than one $(\mathrm{KI}<1)$ is deemed acceptable for irrigation. In this study, the KI of the water sample ranged from 0.40 to 1.35 with an average level was 0.82 (Table 6). Thus, one region (S4) only has a value greater than 1 . This suggests that surface water from this site is deemed unfit for irrigation based on Kelly's ratio (Table 7), which may also be due to intense cation exchange, which provides excess $\mathrm{Na}^{+}$[67].

\subsubsection{Magnesium Hazard (MH)}

Calcium and magnesium in most waters maintain a state of equilibrium. A high level of $\mathrm{MH}(>50 \%)$ in a water sample causes soil alkalinity; moreover, a considerable quantity of water is adsorbed between magnesium and clay particles, reducing the soil's infiltration ability and negatively impacting crop yields [32,49]. The $\mathrm{MH}$ of water samples ranged from 35.97 to $41.43 \%$ (mean $=36.93 \%$ ) (Table 6 ). All of the samples are below $50 \%$, making them appropriate for irrigation. (Table 7).

\subsubsection{Potential Salinity (PS)}

The $\mathrm{Cl}^{-}$concentration plus half of the $\mathrm{SO}_{4}{ }^{-}$concentration equals potential salinity (PS). PS is another another water quality parameter-based index for classifying irrigation water [29]. It has been reported that the salts with low solubility precipitate and accumulate in the soil for irrigation, whereas salts with high solubility enhance the salinity of the soil [70]. In this study, the value of PS in water samples varied from 5.54 to $18.67 \mathrm{meq} \mathrm{L}^{-1}$, 
with a mean of 11.40 meq $\mathrm{L}^{-1}$ (Table 6). That means all samples are classified as injurious to unsatisfactory (Table 7).

\subsubsection{Residual Sodium Carbonate (RSC)}

RSC is a useful index for assessing the suitability of irrigation water because it evaluates the relationship between the quantity of carbonate and bicarbonate and the total of calcium and magnesium [49]. As the water in the soil becomes more concentrated, waters with high concentrations of $\mathrm{HCO}_{3}{ }^{-}$have a propensity to precipitate $\mathrm{Ca}^{2+}$ and $\mathrm{Mg}^{2+}$. As a result of the deposition of sodium carbonate, soils watered with high RSC water might become unproductive [50].

Irrigation is typically deemed safe when RSC levels are less than $1.25 \mathrm{meq} \mathrm{L}^{-1}$. Water with an RSC of 1.25 to 2.5 meq $\mathrm{L}^{-1}$ is classified as marginal and can be utilised with proper irrigation management and soil salinity testing in the laboratory. RSC levels of more than $2.5 \mathrm{meq} \mathrm{L}-1$ are considered inappropriate for irrigation [31,40]. In this study, all of the samples are safe for irrigation (Table 7).

\subsubsection{Total Hardness (TH)}

The natural accumulation of calcium and magnesium ions and salts, or both, causes hardness in water. Total hardness is the sum of calcium and magnesium hardness. All of the surface water samples fall into the soft water category, according to the total hardness (TH) categorization of groundwater. The hardness values range from 11.11 to $22.44 \mathrm{meq} \mathrm{L}^{-1}$ with a mean value of $15.69 \mathrm{meq} \mathrm{L}^{-1}$ (Table 6). The maximum allowable limit of TH for irrigation purposes is 60 meq L ${ }^{-1}$ and the most desirable limit is 120 meq L $\mathrm{L}^{-1}$ as according to Durfor and Becker [34]. All sites in this study are classified as soft (Table 7).

\subsubsection{Irrigation Water Quality Index (IWQI)}

The evaluation of IWQI is based on the idea of comparing water quality parameters to particular criteria, and it defines irrigation water quality as a single number, avoiding complicated data intervals in water quality analyses. [71]. The irrigation water quality index is calculated using the prescribed water consumption limits for all soil types. Table 3 shows the water quality categorization based on WQI values. The calculation of WQI for water samples is shown in Table 6. In this study, the value of IWQI in water samples varied from 40.26 to 114.82 with a mean value of 77.96 . The samples of region S1 (intake of the canal) showed good water, the samples of region S2 (after mixing with the water at the Faraskour drain) showed poor water quality, samples of regions S3 (after mixing with the El-Serw drain) and S5 (before El-Sahara) fell under the very poor water category and samples of region S4 (after mixing with the Hadous drain) showed unsuitable water.

\section{Conclusions}

Based on the present results, it is clear that mixing El-Salam Canal irrigation water with the agricultural drainage water from different drains decreases the quality of irrigation water and the quality is reduced gradually from the west (inlet from the Nile) to the east (toward Sinai) i.e., as the amount of drainage water added is increasing. Additionally, the last drain (Hadous) was the most polluted drain, and its effluent greatly changes the irrigation water quality. It is recommended to apply suitable treatments to the drainage water before mixing with the irrigation water of El-Salam Canal to increase the quality of irrigation water for crops, particularly for the Hadous drain. Further study is recommended to evaluate the efficacy of naturally growing hydrophytes in various drains as eco-friendly phytoremediators.

Supplementary Materials: The following are available online at https:/ / www.mdpi.com/article/10 $.3390 / w 13172428 /$ s1, Table S1: Factors used in calculating irrigation water quality index in water samples collected from different sites (S1-S5) along the El-Salam Canal, Table S2: Pearson's correlation matrix various water parameters and heavy metals from five sites along El-Salam Canal, Egypt. 
Author Contributions: Conceptualization, Y.A.E.-A. and A.M.A.-E.; validation, Y.A.E.-A., G.B. and A.M.A.-E.; formal analysis, Y.A.E.-A., W.K.K. and A.M.A.-E.; investigation, Y.A.E.-A., G.B., H.F., N.A.M. and A.M.A.-E.; writing-original draft preparation, Y.A.E.-A., W.K.K., G.B. and A.M.A.-E.; writing-review and editing, Y.A.E.-A., W.K.K., G.B., H.F., N.A.M. and A.M.A.-E. All authors have read and agreed to the published version of the manuscript.

Funding: The Researchers Supporting Project number (RSP-2021/201) King Saud University, Riyadh, Saudi Arabia.

Institutional Review Board Statement: Not applicable.

Informed Consent Statement: Not applicable.

Data Availability Statement: Not applicable.

Acknowledgments: The author extends their appreciation to The Researchers Supporting Project number (RSP-2021/201) King Saud University, Riyadh, Saudi Arabia.

Conflicts of Interest: The authors declare no conflict of interest.

\section{References}

1. Bhuyan, M.; Bakar, M.; Sharif, A.S.M.; Hasan, M.; Islam, M. Water quality assessment using water quality indicators and multivariate analyses of the old Brahmaputra River. Pollution 2018, 4, 481-493.

2. Bano, I.; Arshad, M. Climatic changes impact on water availability. In Perspectives on Water Usage for Biofuels Production; Arshad, M., Ed.; Springer: Cham, Switzerland, 2018; pp. 39-54.

3. Yıldız, S.; Karakuş, C.B. Estimation of irrigation water quality index with development of an optimum model: A case study. Environ. Dev. Sustain. 2019, 22, 4771-4786. [CrossRef]

4. Hinkel, J.; Aerts, J.C.; Brown, S.; Jiménez, J.A.; Lincke, D.; Nicholls, R.J.; Scussolini, P.; Sanchez-Arcilla, A.; Vafeidis, A.; Addo, K.A. The ability of societies to adapt to twenty-first-century sea-level rise. Nat. Clim. Chang. 2018, 8, 570-578. [CrossRef]

5. El-Amier, Y.A.; El-Zeiny, A.; El-Halawany, E.-S.F.; Elsayed, A.; El-Esawi, M.A.; Noureldeen, A.; Darwish, H.; Al-Barty, A.; Elagami, S.A. Environmental and stress analysis of wild plant habitat in River Nile Region of Dakahlia Governorate on basis of geospatial techniques. Sustainability 2021, 13, 6377. [CrossRef]

6. Ashour, M.; El Attar, S.; Rafaat, Y.; Mohamed, M. Water resources management in Egypt. J. Eng. Sci. 2009, 37, 269-279. [CrossRef]

7. Abdel-Gawad, S. Water quality challenges facing Egypt. In Comparative Risk Assessment and Environmental Decision Making; Linkov, I., Ramadan, A.B., Eds.; Springer: Dordrecht, The Netherlands, 2004; pp. 335-347.

8. Abd-Elmabod, S.K.; Fitch, A.C.; Zhang, Z.; Ali, R.R.; Jones, L. Rapid urbanisation threatens fertile agricultural land and soil carbon in the Nile delta. J. Environ. Manag. 2019, 252, 109668. [CrossRef]

9. El-Alfy, M.A.; El-Amier, Y.A.; El-Eraky, T.E. Land use/cover and eco-toxicity indices for identifying metal contamination in sediments of drains, Manzala Lake, Egypt. Heliyon 2020, 6, e03177. [CrossRef]

10. Abdel-Shafy, H.I.; Kamel, A.H. Groundwater in Egypt issue: Resources, location, amount, contamination, protection, renewal, future overview. Egypt. J. Chem. 2016, 59, 321-362.

11. Loutfy, N.M. Reuse of wastewater in Mediterranean region, Egyptian experience. In Waste Water Treatment and Reuse in the Mediterranean Region; Barceló, D., Petrovic, M., Eds.; Springer: Heidelberg, Germany, 2010; pp. 183-213.

12. Omran, E.-S.E.; Negm, A.M. Egypt's Environment from Satellite. In Environmental Remote Sensing in Egypt; Elbeih, S.F., Negm, A.M., Kostianoy, A., Eds.; Springer: Cham, Switzerland, 2020; pp. 23-91.

13. Othman, A.A.; Rabeh, S.A.; Fayez, M.; Monib, M.; Hegazi, N.A. El-Salam canal is a potential project reusing the Nile Delta drainage water for Sinai desert agriculture: Microbial and chemical water quality. J. Adv. Res. 2012, 3, 99-108. [CrossRef]

14. Assar, W.; Ibrahim, M.G.; Mahmod, W.; Fujii, M. Assessing the agricultural drainage water with water quality indices in the El-Salam Canal mega project, Egypt. Water 2019, 11, 1013. [CrossRef]

15. Khalifa, W. Simulation of water quality for the El-Salam canal in Egypt. In Water Pollution; Brebbia, C.A., Ed.; WIT Press: Southampton, UK, 2014; pp. 27-37.

16. Saravanan, A.; Kumar, P.S.; Jeevanantham, S.; Karishma, S.; Tajsabreen, B.; Yaashikaa, P.; Reshma, B. Effective water/wastewater treatment methodologies for toxic pollutants removal: Processes and applications towards sustainable development. Chemosphere 2021, 280, 130595. [CrossRef] [PubMed]

17. El-Amier, Y.A.; Elsayed, A.; El-Esawi, M.A.; Noureldeen, A.; Darwish, H.; Fakhry, H. Optimizing the biosorption behavior of Ludwigia stolonifera in the removal of lead and chromium metal ions from synthetic wastewater. Sustainability 2021, $13,6390$. [CrossRef]

18. Rahmat, S.T.; Rozana, M.; Kian, T.W.; Kawamura, G.; Matsuda, A.; Lockman, Z. One-dimensional $\alpha$-Fe ${ }_{2} \mathrm{O}_{3}$ nanowires formation by high temperature oxidation of iron and their potential use to remove $\mathrm{Cr}$ (VI) ions. In 1-Dimensional Metal Oxide Nanostructures; Lockman, Z., Ed.; CRC Press: Boca Raton, FL, USA, 2018; pp. 115-142.

19. El-Amier, Y.A.; Bonanomi, G.; Al-Rowaily, S.L.; Abd-ElGawad, A.M. Ecological risk assessment of heavy metals along three main drains in Nile Delta and potential phytoremediation by macrophyte plants. Plants 2020, 9, 910. [CrossRef] 
20. Zaman, M.; Shahid, S.A.; Heng, L. Guideline for Salinity Assessment, Mitigation and Adaptation Using Nuclear and Related Techniques Null; Springer Nature: Cham, Switzerland, 2018. [CrossRef]

21. Pesce, S.F.; Wunderlin, D.A. Use of water quality indices to verify the impact of Córdoba City (Argentina) on Suquía River. Water Res. 2000, 34, 2915-2926. [CrossRef]

22. Shil, S.; Singh, U.K.; Mehta, P. Water quality assessment of a tropical river using water quality index (WQI), multivariate statistical techniques and GIS. Appl. Water Sci. 2019, 9, 168. [CrossRef]

23. Mostafa, A. Development of Water Quality Indicators and Atlas of Drainage Water Quality Using GIS Tools; Technical report submitted to the NAWQAM project-Egypt; CIDA-DRTPC-MWRI: Giza, Egypt, 2002; p. 85.

24. Assar, W.; Ibrahim, M.G.; Mahmod, W.; Allam, A.; Tawfik, A.; Yoshimura, C. Effect of water shortage and pollution of irrigation water on water reuse for irrigation in the Nile Delta. J. Irrig. Drain. Eng. 2020, 146, 05019013. [CrossRef]

25. Piper, C.S. Soil and Plant Analysis; Interscience Publishers, Inc: New York, NY, USA, 1947.

26. Jackson, M.L. Soil Chemical Analysis; Constable and Co Ltd.: London, UK, 1962; Volume 497.

27. Pierce, W.C.; Haenisch, E.L.; Sawyer, D.T. Quantitative Analysis; Wiley Toppen: Tokyo, Japan, 1958.

28. APHA. Standard Methods for the Examination of Water and Wastewater, 20th ed.; American Public Health Association: Washington, DC, USA, 1999.

29. Doneen, L.D. Notes on Water Quality in Agriculture; Department of Water Science and Engineering, University of California: Oakland, CA, USA, 1964.

30. Richards, L.A. Diagnosis and Improvement of Saline and Alkali Soils; United State Department of Agriculture: Washington, DC, USA, 1954; Volume 78.

31. Wilcox, L. Classification and Use of Irrigation Waters; United State Department of Agriculture: Washington, DC, USA, 1955.

32. Ravikumar, P.; Somashekar, R.; Angami, M. Hydrochemistry and evaluation of groundwater suitability for irrigation and drinking purposes in the Markandeya River basin, Belgaum District, Karnataka State, India. Environ. Monit. Assess. 2011, 173, 459-487. [CrossRef]

33. Paliwal, K. Irrigation With Saline Water; IARI: New Delhi, India, 1972; Volume 198.

34. Durfor, C.N.; Becker, E. Public Water Supplies of the 100 Largest Cities in the United States, 1962; US Government Printing Office: Boston, MA, USA, 1964.

35. Srinivasamoorthy, K.; Gopinath, M.; Chidambaram, S.; Vasanthavigar, M.; Sarma, V. Hydrochemical characterization and quality appraisal of groundwater from Pungar sub basin, Tamilnadu, India. J. King Saud Univ. Sci. 2014, 26, 37-52. [CrossRef]

36. Kelly, W. Permissible composition and concentration of irrigated waters. In Proceedings of the American Society of Civil Engineers 1940, Reston, VA, USA, January 1940; Volume 66, pp. 607-613.

37. Şener, Ş.; Şener, E.; Davraz, A. Evaluation of water quality using water quality index (WQI) method and GIS in Aksu River (SW-Turkey). Sci. Total Environ. 2017, 584, 131-144. [CrossRef] [PubMed]

38. Singh, A.K.; Mondal, G.C.; Kumar, S.; Singh, T.B.; Tewary, B.K.; Sinha, A. Major ion chemistry, weathering processes and water quality assessment in upper catchment of Damodar River basin, India. Environ. Geol. 2008, 54, 745-758. [CrossRef]

39. Das, S.; Nag, S. Deciphering groundwater quality for irrigation and domestic purposes-a case study in Suri I and II blocks, Birbhum District, West Bengal, India. J. Earth Syst. Sci. 2015, 124, 965-992. [CrossRef]

40. Eaton, F.M. Significance of carbonates in irrigation waters. Soil Sci. 1950, 69, 123-134. [CrossRef]

41. Roy, S.; Akhtaruzzaman, M.; Nath, B. Spatio-seasonal variations of salinity and associated chemical properties in the middle section of Karnaphuli river water, Chittagong, Bangladesh using laboratory analysis and GIS technique. Int. J. Environ. Sci. Dev. 2020, 11, 372-382.

42. Vincy, M.; Brilliant, R.; Pradeepkumar, A. Hydrochemical characterization and quality assessment of groundwater for drinking and irrigation purposes: A case study of Meenachil River Basin, Western Ghats, Kerala, India. Environ. Monit. Assess. 2015, 187, 1-19. [CrossRef]

43. WHO. Guidelines For Drinking Water Quality, 4th ed.; World Health Organization: Geneva, Switzerland, 2011; Volume 38, pp. 104-108.

44. Zhang, W.; Ma, L.; Abuduwaili, J.; Ge, Y.; Issanova, G.; Saparov, G. Hydrochemical characteristics and irrigation suitability of surface water in the Syr Darya River, Kazakhstan. Environ. Monit. Assess. 2019, 191, 572. [CrossRef] [PubMed]

45. FAO. Water Quality for Agriculture. Irrigation and Drainage; Food and Agriculture Organization: Rome, Italy, 1994.

46. Tume, P.; González, E.; King, R.W.; Monsalve, V.; Roca, N.; Bech, J. Spatial distribution of potentially harmful elements in urban soils, city of Talcahuano, Chile. J. Geochem. Explor. 2018, 184, 333-344. [CrossRef]

47. Piper, A.M. A graphic procedure in the geochemical interpretation of water-analyses. Eos Trans. Am. Geophys. Union 1944, 25, 914-928. [CrossRef]

48. Tahmasebi, P.; Mahmudy-Gharaie, M.H.; Ghassemzadeh, F.; Karouyeh, A.K.J. Assessment of groundwater suitability for irrigation in a gold mine surrounding area, NE Iran. Environ. Earth Sci. 2018, 77, 766. [CrossRef]

49. Khalid, S.J. An assessment of groundwater quality for irrigation and drinking purposes around brick kilns in three districts of Balochistan province, Pakistan, through water quality index and multivariate statistical approaches. J. Geochem. Explor. 2019, 197, 14-26.

50. Li, P.; Zhang, Y.; Yang, N.; Jing, L.; Yu, P.J. Major ion chemistry and quality assessment of groundwater in and around a mountainous tourist town of China. Expos. Health 2016, 8, 239-252. [CrossRef] 
51. Huo, C.; Qian, H.; Wu, H.J. Environmental background values of shallow groundwater in the Guanzhong Basin. Water Divers. Water Conserv. Sci. Technol. 2016, 14, 99-106.

52. Esposito, F.; Nardone, A.; Fasano, E.; Scognamiglio, G.; Esposito, D.; Agrelli, D.; Ottaiano, L.; Fagnano, M.; Adamo, P.; Beccaloni, E. A systematic risk characterization related to the dietary exposure of the population to potentially toxic elements through the ingestion of fruit and vegetables from a potentially contaminated area. A case study: The issue of the "Land of Fires" area in Campania region, Italy. Environ. Pollut. 2018, 243, 1781-1790. [PubMed]

53. USEPA. Screening Level Ecological Risk Assessment Protocol for Hazardous Waste Combustion Facilities; Appendix E: Toxicity Reference Values; EPA530-D99-001C; USA EPA: Dallas, TX, USA, 1999; Volume 3.

54. EU. Heavy Metals in Wastes, European Commission on Environment. 2002. Available online: http://ec.europa.eu/environment/ waste/studies/pdf/heavy_metalsreport.pdf (accessed on 1 February 2002).

55. He, Y.; Men, B.; Yang, X.; Li, Y.; Xu, H.; Wang, D. Relationship between heavy metals and dissolved organic matter released from sediment by bioturbation/bioirrigation. J. Environ. Sci. 2019, 75, 216-223. [CrossRef] [PubMed]

56. Abdel-Baky, T.; Hagras, A.; Hassan, S.; Zyadah, M. Environmental impact assessment of pollution in Lake Manzala, I-Distribution of some heavy metals in water and sediment. J. Egypt. Ger. Soc. Zool. 1998, 26, 25-38.

57. Dang, P.; Gu, X.; Lin, C.; Xin, M.; Zhang, H.; Ouyang, W.; Liu, X.; He, M.; Wang, B. Distribution, sources, and ecological risks of potentially toxic elements in the Laizhou Bay, Bohai Sea: Under the long-term impact of the Yellow River input. J. Hazard. Mat. 2021, 413, 125429. [CrossRef] [PubMed]

58. Reimann, C.; Filzmoser, P.; Hron, K.; Kynčlová, P.; Garrett, R. A new method for correlation analysis of compositional (environmental) data-A worked example. Sci. Total Environ. 2017, 607, 965-971. [CrossRef] [PubMed]

59. D'Sa, E.J.; DiMarco, S.F. Seasonal variability and controls on chromophoric dissolved organic matter in a large river-dominated coastal margin. Limnol. Oceanogr. 2009, 54, 2233-2242. [CrossRef]

60. Mendiguchía, C.; Moreno, C.; García-Vargas, M. Evaluation of natural and anthropogenic influences on the Guadalquivir River (Spain) by dissolved heavy metals and nutrients. Chemosphere 2007, 69, 1509-1517. [CrossRef]

61. Jia, Z.; Li, S.; Liu, Q.; Jiang, F.; Hu, J. Distribution and partitioning of heavy metals in water and sediments of a typical estuary (Modaomen, South China): The effect of water density stratification associated with salinity. Environ. Pollut. 2021, 287, 117277. [CrossRef] [PubMed]

62. Adams, S.; Titus, R.; Pietersen, K.; Tredoux, G.; Harris, C. Hydrochemical characteristics of aquifers near Sutherland in the Western Karoo, South Africa. J. Hydrol. 2001, 241, 91-103. [CrossRef]

63. Zhang, J.; Zhou, F.; Chen, C.; Sun, X.; Shi, Y.; Zhao, H.; Chen, F. Spatial distribution and correlation characteristics of heavy metals in the seawater, suspended particulate matter and sediments in Zhanjiang Bay, China. PLoS ONE 2018, 13, e0201414. [CrossRef]

64. Kierczak, J.; Pędziwiatr, A.; Waroszewski, J.; Modelska, M. Mobility of Ni, Cr and Co in serpentine soils derived on various ultrabasic bedrocks under temperate climate. Geoderma 2016, 268, 78-91. [CrossRef]

65. Dragović, S.; Mihailović, N.; Gajić, B. Heavy metals in soils: Distribution, relationship with soil characteristics and radionuclides and multivariate assessment of contamination sources. Chemosphere 2008, 72, 491-495. [CrossRef] [PubMed]

66. Raju, N.J. Hydrogeochemical parameters for assessment of groundwater quality in the upper Gunjanaeru River basin, Cuddapah District, Andhra Pradesh, South India. Environ. Geol. 2007, 52, 1067-1074. [CrossRef]

67. Xu, P.; Feng, W.; Qian, H.; Zhang, Q. Hydrogeochemical characterization and irrigation quality assessment of shallow groundwater in the Central-Western Guanzhong Basin, China. Int. J. Environ. Res. Public Health 2019, 16, 1492. [CrossRef]

68. Fipps, G. Irrigation Water Quality Standards and Salinity Management Strategies. 2003. Available online: https://hdl.handle. net/1969.1/87829 (accessed on 30 April 2003).

69. Heras, J.D.L.; Mañas, P. Reclaimed wastewater to irrigate olive groves and vineyards: Effects on soil properties. Agronomy 2020, 10, 649. [CrossRef]

70. Gholami, S.; Srikantaswamy, S. Analysis of agricultural impact on the Cauvery river water around KRS dam. World Appl. Sci. J. 2009, 6, 1157-1169.

71. Ghazaryan, K.; Chen, Y. Hydrochemical assessment of surface water for irrigation purposes and its influence on soil salinity in Tikanlik oasis, China. Environ. Earth Sci. 2016, 75, 383. [CrossRef] 